\title{
Aktivitas Biologi Enam Jenis Ekstrak Tumbuhan Famili Asteraceae terhadap Larva Spodoptera litura Fabricius (Lepidoptera: Noctuidae)
}

\section{RATNA SARI DEWI DAN DADANG}

\author{
Laboratorium Fisiologi dan Toksikologi serangga \\ Jurusan Hama dan Penyakit Tumbuhan, Faperta, IPB \\ Jl. Kamper, Kampus JPB Darmaga, Bogor 16680
}

(diterima Mei 2004, disetujui Agustus 2004)

\begin{abstract}
Biological Activity of Six Plant Extracts from Asteraceae on Spodoptera litura Fabricius (Lepidoptera : Noctuidae) Larvae. Asreracese is one of plant family that is known to have insecticidal activity to several insect pests, such as Parthenium argentatum, Chysanthemum cimeariafolium, and Ageratum houstoneanum. The aim of this study is to explore other asteraceac species in order to search for insecticidal activity to Spodoptera litura Fabricius (Lepidoptera: Noctuidae). Six species, Blumea balsamifera (leaf). Elephanthopus scaber (leaf), Gymura praimbens (caf) Artemisia vulgaris (leaf) Sontbus arvensis (leaf) and Heliontbus annus (seed) were used in this study. Plant extracts were obtained by maseration method using methanol. The extracts were bioassayed to the second instar larvae of $S$. litura to evaluate the mortality, antifeedant and growth regulation activity. Extracts of B. balsamifsra and E. scaber have high antifeedant activiny at $5 \%$ by reducing larval feeding $87.7 \%$ and $81.8 \%$ in no choice test, and $94.1 \%$ and $86.1 \%$ in choice test method, respecrively. Extracts of H. ammits, A. vulgaris, and E. siaber prolonged the development of larvac by $4.9,4.1,3.9$ days, respectively. While extract of $H$. cnntus caused mortality of larvac by $86 \%$ at $5 \%$.
\end{abstract}

KEY WORDS: Antifeedant, asteraceae, growth regulation, mortaliry, Spodoptera litura.

\section{PENDAHULUAN}

Kedelai (Glycine max (L.) Merrill) merupakan salah satu tanaman pangan utama yang sejak PELITA IV telah dimasukkan dalam program pangan nasional. Tanaman ini sangat berperan penting dalam upaya perbaikan gizi masyarakat karena mempunyai kandungan protein yang tinggi, sumber lemak, vitamin, dan mineral (Amang dan Sawit, 1996).
Peningkatan permintaan kedelai selama beberapa tahun terakhir cukup pesat baik untuk konsumsi manusia maupun untuk pakan ternak. Namun produksi kedelai dalam negeri belum mampu memenuhi permintaan yang ada. Produksi kedelai nyata per hektar di Indonesia lebih rendah dibandingkan dengan potensi hasilnya.

Salah satu faktor yang menyebabkan rendahnya hasil kedelai di Indonesia adalah adanya serangan hama. Ulat grayak, Spodoptera litura Fabricius 
(Lepidoptera: Noctuidae) merupakan hama penting pada tanaman kedelai di Indonesia. Kehilangan hasil akibat serangan hama ini pada tanaman kedelai berumur 30 hari mencapai $28,8 \%$ dan pada umur 79 hari mencapai $60,2 \%$ (Arifin, 1989).

Berbagai teknik pengendalian terhadap hama ini masih terus dikembangkan misalnya dengan menggunakan musuh alami, salah sarunya adalah parasitoid. Namun pengendalian dengan menggunakan parasitoid ini memerlukan pengetahuan dan keahlian yang tidak semua petani memilikinya, di samping itu hasilnya tidak langsung cepat dapat dievaluasi. Hal ini mendorong penggunaan insektisida sintetik sebagai salah satu cara pengendalian yang biasa dan paling dominan dilakukan untuk menyelamatkan hasil atau mengurangi kerugian yang lebih besar. Namun penggunaan yang tidak bijaksana dapat menimbulkan dampak negatif yang tidak diinginkan diantaranya terjadi resistensi dan resurjensi, adanya ledakan hama sekunder, berpengaruh buruk pada organisme bukan sasaran, residu pada produk, membahayakan kesehatan manusia, hewan, dan lingkungan (Metcalf, 1982; Tarumingkeng, 1992; Regnault-Roger, 1997).

Bertolak dari permasalahan yang timbul karena penggunaan insektisida sintetik, dan semakin besarnya tuntutan masyarakat (konsumen) tentang keamanan produk pertanian dan masalah residu pestisida, kini banyak dilakukan penelitian untuk mendapatkan senyawa baru dari tumbuhan yang sering disebut insektisida botani sebagai alternatif pengendalian hama secara kimiawi.

Salah satu famili tumbuhan yang berpotensi sebagai sumber insektisida botani adalah famili Asteracea, Beberapa spesies anggota famili Asteraceae ini memiliki aktivitas biologi seperti ekstrak Parthenium argentatum Gray yang dapat menghambat perkembangan larva Helionthis ₹ea dan S. littra (Isman and Rodriguez, 1983). Sclain itu be-berapa penelitian juga telah menemukan senyawa dari tumbuhan yang bersifat insektisida, diantaranya senyawa piretrin yang diisolasi dari Chrysanthemum cinerariafolium, senyawa prekosen I dan II dari Ageratum boustonianum yang bersifat sebagai anti hormon juvenil pada beberapa spesies serangga (Sicbertz et al., 1990)

Dalam upaya mencari tumbuhantumbuhan yang dapat mengganggu kehidupan serangga beberapa pendekatan dapat dilakukan seperti (1) penapisan yang didasarkan pada kedekatan spesies terutama dalam satu famili yang telah diketahui memberikan pengaruh negatif pada kehidupan serangga, (2) terhadap tumbuh-tumbuhan yang sering dijadikan obat tradisional, (3) tumbuh-tumbuhan yang secara tradisional telah digunakan sebagai agens pengendalian serangga, dan (4) penapisan sacara acak.

Penelitian ini bertujuan untuk mempelajari kemungkinan ditemukannya spesies-spesies baru dari famili Asteraceac yang memiliki aktivitas biologi yang dapat mempengaruhi aktivitas 
makan, mortalitas, dan perkembangan larva S. litura.

\section{BAHAN DAN METODE}

Penelitian dilaksanakan di Laboratorium Fisiologi dan Toksikologi Serangga, Jurusan Hama dan Penyakit Tumbuhan, Fakultas Pertanian, Institut Pertanian Bogor yang merupakan satu seri penelitian dalam pengembangan insektisida botani.

\section{Sumber Ekstrak}

Bahan tumbuhan yang digunakan sebagai sumber ekstrak yairu daun Blumea balsamifera, daun Elephantopus scaber, biji Heliantbus annus, daun Gynura procumbens, daun Artemisia vilgaris yang diambil dari dacrah sekitar Bogor, dan daun Soncbus arvensis yang didapatkan dari Kebun Raya Cibodas.

\section{Perbanyakan Serangga Uji}

Larva S. Ritura diambil dari pertanaman talas di daerah Sindang Barang, Bogor, lalu dibiakkan di Laboratorium. Larva diberi makan daun talas. Pada saat akan berpupa, kotak plastik diberi serbuk gergaji steril sebagai media untuk berpupa. Imago yang muncul diberi larutan madu murni $(10 \%)$ yang diresapkan pada kapas. Larva yang digunakan untuk pengujian yaitu larva instar II.

\section{Pembuatan Ekstrak}

Bagian dari tumbuhan uji yang telah dikering-anginkan selama 1 minggu digunting menjadi potongan-potongan kecil kemudian digiling dengan menggunakan blender hingga diperoleh serbuk halus. Serbuk masing-masing spesics tumbuhan direndam dalam pelarut metanol dengan perbandingan 1:10 selama 48 jam sambil diaduk dengan menggunakan pengaduk magnetik. Setelah 48 jam rendaman disaring dengan corong Buchner yang dialasi kertas saring. Pelarut metanol dalam filtrat diuapkan dengan menggunakan rotan evaporator pada suhu $50^{\prime \prime} \mathrm{C}$ dan tekanan $400-700 \mathrm{mmHg}$ hingga dihasilkan ekstrak kasar. Ekstrak kasar kemudian disimpan dalam refrigerator pada suhu $5 \pm 1^{\prime \prime} \mathrm{C}$ hingga akan digunakan dalam pengujian.

\section{Metode Pengujian}

\section{Pengujian Mortalitas Larva}

Konsentrasi ekstrak yang digunakan yaitu $5,3,1$, dan $0,5 \%$, serta kontrol dengan pelarut metanol-aseton dengan perbandingan 1:1 dan ditambah latron $77 \mathrm{~L} 0,1 \%$, kecuali untuk ekstrak $H$. annus menggunakan pelarut metanol $10 \%$ dan air. Setiap konsentrasi uji dilakukan 5 ulangan dengan sepuluh ckor larva untuk setiap ulangannya. Metode yang digunakan yaitu metode residu pada daun.

Sebanyak $30 \mu \mathrm{l}$ larutan ekstrak disebarkan secara merata pada kedua sisi lempengan daun yang berdiameter $2 \mathrm{~cm}$ dengan menggunakan microsyninge. Setelah pelarut menguap, 4 lempeng daun dimasukkan ke cawan petri yang dialasi kertas tissue. Kemudian 10 ekor 
larva $S$. litura instar II dimasukkan ke dalamya. Larva diberi daun berperlakuan selama 3 hari kemudian diganti dengan daun segar tanpa perlakuan.

Pengamatan dilakukan hingga larva mencapai instar akhir (instar IV) dengan mengamati kematian larva dan lama perkembangannya. Data kematian dihitung dalam persen kematian, yaitu perbandingan serangga yang mati dengan jumlah serangga perlakuan.

\section{Pengujian Aktivitas Makan}

Konsentrasi uji yang digunakan sama dengan uji mortalitas larva. Metode yang digunakan yaitu metode pilihan dan tanpa pilihan. Pada metode pilihan, 4 lempeng daun yang terdiri dari 2 lempeng daun berperlakuan dan 2 lempeng daun kontrol diletakkan secara bergiliran pada cawan petri yang dialasi kertas tissue, kemudian ke dalamnya dimasukkan 10 ekor larva. Lntuk metode tanpa pilihan, 4 lempeng daun berperlakuan sama dimasukkan ke cawan petri dan ke dalamnya dimasukkan 10 ekor larva. Setelah 24 jam daun perlakuan diambil dan dikeringkan dalam oven pada suhu $100^{\circ} \mathrm{C}$ selama 48 jam untuk mengetahui berat kering akhir dan dihitung berat/ bobot daun yang dimakan.

Untuk menentukan kadar air daun, dua lempeng daun dari masingmasing daun dikering-anginkan dalam oven pada suhu $100^{\circ} \mathrm{C}$ selama 48 jam.

Aktivitas penghambatan makan dihitung dengan rumus:

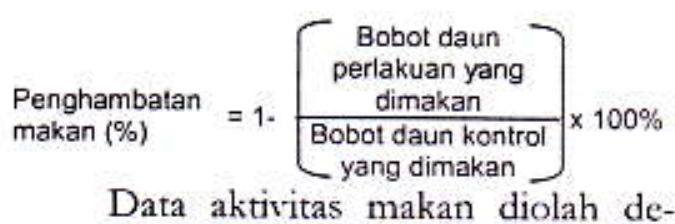
ngan sidik ragam (ANOVA-Anabisis of Variance) dan nilai tengah diuji Duncan (Steel and Torrie, 1993) dengan program SAS (Statistial Analyits System).

\section{HASIL DAN PEMBAHASAN}

\section{Pengaruh Ekstrak Terhadap Mor- talitas Larva S. litura}

Dari hasil pengujian yang dilakukan, empat dari enam ekstrak yang diuji secara umum memiliki sifat insektisida yaitu ekstrak B. baliamifera, E. siaber, $H$. annuts, dan $A$. vu/garis, yang efek kematiannya relatif cepat. Kematian larva yang tinggi terjadi pada larva instar II dan kebanyakan pada saat larva masih memakan daun perlakuan. Setelah daun diganti dengan daun segar tanpa perlakuan, larva yang bertahan hidup dapat dipastikan dapat mencapai instar akhir (instar VI). Gejala kematian yang terlihat adalah larva yang kcracunan tubuhnya mengecil dan mengering.

Secara umum kematian larva cenderung meningkat dengan semakin meningkatnya konsentrasi. Menurut penggolongan aktivitas ekstrak berdasarkan mortalitas larva (Prijono, 1998), ekstrak B. balsamifera, E. scaber, $H$. annnus, $A$. vulgaris memiliki akrivitas berturut-turut adalah tidak aktif sampai sedang (4,0$52,1 \%)$; sedang sampai cukup kuat $(44,0-$ $64,0 \%)$; sedang sampai agak kuat $(54,0-$ $86,0 \%$; agak lemah sampai agak kuat 
$(28,0-78,0 \%)$ pada larva instar 2 dan tidak aktif pada larva yang telah masuk instar 3 atau dengan kata lain senyawa yang terkandung dalam ekstrak tidak begitu berpengaruh terhadap mortalitas larva pada saat larva sudah mencapai instar III. Sedangkan dua ekstrak yang lain yaitu $G$. procumbens dan $S$, anensis tidak aktif sama sekali (Tabel 1).

\section{Pengaruh Ekstrak terhadap Peng- hambatan Aktivitas Makan Larva}

Secara umum keenam jenis ekstrak yang diujikan dapat memiliki sifat sebagai penghambat makan (feeding inhibitor). Aktivitas penghambatan dari keenam jenis ekstrak ini berkisar antara lemah sampai agak kuat baik pada metode pilihan maupun non-pilihan (Tabel 2). Pada metode non pilihan ekstrak $B$. balsamifera, E. Saber, H. annums, G. procumbens, A. unlgaris, dan S. amensis memiliki aktivitas penghambatan secara berturut-turut berkisar antara 31,2$87,8^{\circ} \% ; 52,0-81,8^{\%} \% ; 32,3-70,5^{\circ} \% ; 10,4-$ $61,8 \% ; 40,7-72,1 \%$; dan $18,9-41,2 \%$. Sedangkan pada metode pilihan yairu 31,0 $94,1 \% ; \quad 58,1-86,1 \% ; 21,5-66,4 \% ; \quad 7,5-$ $14,8 \% ; \quad 30,5-62,6 \%$ dan $32,3-47,1 \%$ (Tabel 2). Penghambatan ini cenderung meningkat dengan meningkatnya konsentrasi kecuali pada perlakuan ekstrak H. annuss (metode non pilihan) dengan konsentrasi $1 \%$ mengalami penurunan,

Tabel 1. Pengaruh beberapa ekstrak tumbuhan terhadap mortalitas larva $S$. litura pada konsentrasi yang berbeda.

\begin{tabular}{|c|c|c|c|}
\hline \multirow{2}{*}{ Jenis ekstrak } & \multirow{2}{*}{ Konsentrasi $(\%)$} & \multicolumn{2}{|c|}{ Mortalitas Larva (\%) } \\
\hline & & Instar II & Instar III \\
\hline \multirow[t]{5}{*}{ Blumea balsamifera } & 0,0 & 0.0 & 0.0 \\
\hline & 0,5 & 4,0 & 0,0 \\
\hline & 1.0 & 4.1 & 0,0 \\
\hline & 3,0 & 28,0 & 4,0 \\
\hline & 5,0 & 52,1 & 4,0 \\
\hline \multirow[t]{5}{*}{ Elephantopus scaber } & 0,0 & 0,0 & 0,0 \\
\hline & 0.5 & 46,0 & 2,0 \\
\hline & 1,0 & 59,2 & 0,0 \\
\hline & 3.0 & 44,0 & 4,0 \\
\hline & 5,0 & 64,0 & 0.0 \\
\hline \multirow{5}{*}{ Helianthus annuus } & 0.0 & 0,0 & 0.0 \\
\hline & 0.5 & 60,0 & 2,0 \\
\hline & 1,0 & 54,0 & 2,0 \\
\hline & 3.0 & 58.0 & 4,0 \\
\hline & 5,0 & 86,0 & 0.0 \\
\hline \multirow[t]{5}{*}{ Gynura procumbens } & 0,0 & 0,0 & 0.0 \\
\hline & 0.5 & 0.0 & 0.0 \\
\hline & 1,0 & 0,0 & 0.0 \\
\hline & 3,0 & 0,0 & 0,0 \\
\hline & 5.0 & 0.0 & 0.0 \\
\hline \multirow[t]{5}{*}{ Artemisia vuigaris } & 0.0 & 0.0 & 0.0 \\
\hline & 0,5 & 56,0 & 4,0 \\
\hline & 1,0 & 28,0 & 2,0 \\
\hline & 3,0 & 48,0 & 0,0 \\
\hline & 5.0 & 78,0 & 4,0 \\
\hline \multirow[t]{5}{*}{ Sonchus arvensis } & 0,0 & 0,0 & 0,0 \\
\hline & 0,5 & 0,0 & 0,0 \\
\hline & 1,0 & 0,0 & 0,0 \\
\hline & 3,0 & 0,0 & 0,0 \\
\hline & 5,0 & 0,0 & 0,0 \\
\hline
\end{tabular}


Tabel 2. Pengaruh beberapa ekstrak tumbuhan terhadap penghambatan aktivitas makan larva S. litura pada konsentrasi yang berbeda.

\begin{tabular}{|c|c|c|c|}
\hline \multirow{2}{*}{ Jenis ekstrak } & \multirow{2}{*}{ Konsentrasi (\%) } & \multicolumn{2}{|c|}{ Rata-rata penghambatan $\pm \mathrm{sd}^{2}(\%)^{0}$} \\
\hline & & Non-Pilihan & Pilihan \\
\hline \multirow[t]{4}{*}{ Blumea balsamifera } & 0,5 & $31,2 \pm 9,7 \mathrm{c}$ & $31,0 \pm 1,4 d$ \\
\hline & 1,0 & $45.9 \pm 11.4 c$ & $47.9=4,3 c$ \\
\hline & 3.0 & $70,5 \pm 17,4 b$ & $74,7 \pm 0.9 b$ \\
\hline & 5,0 & $87,7 \pm 8,5 a$ & $94,1 \pm 4,9 a$ \\
\hline \multirow[t]{4}{*}{ Elephantopus scaber } & 0,5 & $52,0 \pm 28,4$ & $58,1=23,1 b$ \\
\hline & 1,0 & $65,4 \pm 13,7$ a & $67,8=16,8 \mathrm{ab}$ \\
\hline & 3,0 & $77,3 \pm 14,9$ a & $80,2 \pm 7,1 \mathrm{a}$ \\
\hline & 5.0 & $81,8+28,1 a$ & $86,1 \pm 6,9 a$ \\
\hline \multirow[t]{4}{*}{ Helianthus annuus } & 0,5 & $36,8 \pm 19,2 c$ & $21.5 \pm 10.9 b$ \\
\hline & 1,0 & $32,3 \pm 13,5 c$ & $24,4 \pm 9,8 b$ \\
\hline & 3,0 & $53,1 \pm 9,7 a b$ & $29,3 \pm 10,7 b$ \\
\hline & 5,0 & $70,5 \pm 10,7 a$ & $66,4 \pm 19,7 \mathrm{a}$ \\
\hline \multirow[t]{4}{*}{ Gynura procumbens } & 0.5 & $10,4 \pm 10,4 b$ & $7.5 \pm 8,4 a$ \\
\hline & 1,0 & $35,0=34,4 a b$ & $9.2 \pm 9.4 \mathrm{a}$ \\
\hline & 3,0 & $51,0 \pm 33,2 a$ & $10,5 \pm 12,5 a$ \\
\hline & 5,0 & $61,8 \pm 21,1 \mathrm{a}$ & $14,8+12,2 a$ \\
\hline \multirow[t]{4}{*}{ Artemisia vulgaris } & 0.5 & $40,7=10,0 \mathrm{~b}$ & $30,5 \pm 22,1 \mathrm{a}$ \\
\hline & 1.0 & $41,0=15,9 b$ & $31,3 \pm 34,2 a$ \\
\hline & 3.0 & $60,0=7,6 \mathrm{ab}$ & $35,2 \pm 12,1 \mathrm{a}$ \\
\hline & 5,0 & $72,1=18,9 a$ & $62,6=25,1 \mathrm{a}$ \\
\hline \multirow[t]{4}{*}{ Sonchus arvensis } & 0,5 & $18,9=8,7 b$ & $32,3=23,8 a$ \\
\hline & 1.0 & $24.5=5.5 b$ & $33,6=9,0 \mathrm{a}$ \\
\hline & 3,0 & $33,5 \pm 1,3 a$ & $37,4=26,6 a$ \\
\hline & 5,0 & $41,2 \pm 8,1 \mathrm{a}$ & $47,1=32,4 \mathrm{a}$ \\
\hline
\end{tabular}

${ }^{\circ} \mathrm{sd}=$ standar deviasi. ${ }^{\circ}$ Rataan pada lajur yang sama dan diikuti huruf yang sama tidak berbeda nyata berdasarkan uji Duncan $(\alpha=0,05)$.

namun tidak menunjukkan perbedaan yang nyata.

Persen penghambatan secara umum lebih tinggi pada metode non pilihan dibandingkan dengan metode pilihan, kecuali untuk ekstrak B. Balsami. fera dan E. scaber, persen penghambatan pada metode pilihan lebih tinggi dibandingkan pada metode non pilihan, namun perbedaannya tidak begitu mencolok.

Dari data antara penghambatan makan dan mortalitas larva, tampaknya terdapat korelasi yang positif, yang mana persen penghambatan yang tinggi memberikan kematian yang tinggi. Tetapi jika dilihat per ekstrak terdapat hubungan yang berbanding terbalik dimana secara umum dari persen penghambatan yang tinggi diperoleh kematian larva yang lebih rendah antar ekstrak. Untuk ekstrak B. balsamifera dari persen penghambat-an tertinggi $87,7 \%$ (non pilihan) diper-oleh kematian total sebesar $56,1 \%$, E saber penghambatan $81,8 \%$, kematian $64 \%$, H. annus penghambatan $70,5 \%$, kematian $86,0 \%$, dan $A$. pulgaris penghambatan 72,1 kematian $78,0 \%$.

\section{Pengaruh Ekstrak terhadap Per- kembangan Larva S. litura}

Pengaruh ekstrak terhadap lama perkembangan larva disajikan pada Tabel 3. Secara umum ekstrak dapat memperpanjang perkembangan larra yang bertahan hidup lebih lama diban- 
Tabel 3. Pengaruh ekstrak terhadap perkembangan larva $S$. litura.

\begin{tabular}{|c|c|c|c|c|c|}
\hline \multirow{3}{*}{$\begin{array}{l}\text { Jenis ekstrak } \\
\text { Blumea } \\
\text { balsamifera }\end{array}$} & \multirow{2}{*}{$\frac{\text { Konsentrasi }(\%)}{0,0}$} & \multicolumn{4}{|c|}{ Rata-rata penghambatan $\pm s d^{7}(\%)^{3}$} \\
\hline & & $1,9 \pm 0,3(50) \mathrm{e}$ & $3,3 \pm 0,5(50) \mathrm{e}$ & $5,0 \pm 0,2(50) d$ & $7,2=0,4(50) d$ \\
\hline & 0,5 & $2,6 \pm 0,5(48) d$ & $4,0 \pm 0,7(48) d$ & $5,7 \pm 0,5(48) \mathrm{c}$ & $7,9 \pm 0,8(48) c$ \\
\hline & 1.0 & $3,0 \pm 0,9(45) \mathrm{c}$ & $4,9 \pm 0,5(44) c$ & $6.9 \pm 0.8(44) b$ & $9,3=1,3(44) b$ \\
\hline & 3,0 & $3,3 \pm 0,6(34) b$ & $5,4 \pm 0,6(32) b$ & $7,5 \pm 0,8(31)$ a & $9,8=0,9(31) a$ \\
\hline & 5,0 & $3,6 \pm 0,8(23) a$ & $5,6 \pm 0,7(23) a$ & $7,8=0,8(23) a$ & $10,0 \pm 1,0(23) a$ \\
\hline Elephantopus & 0.0 & $2,1 \pm 0,2(50) c$ & $4,4 \pm 0,5(50) \mathrm{c}$ & $6,2=0,4(50) c$ & $9,0 \pm 0.7(50) c$ \\
\hline \multirow[t]{4}{*}{ scaber } & 0,5 & $2,7 \pm 0,9(28) a$ & $5,0 \pm 1,1(27) b c$ & $8,3 \pm 1,3(27) b$ & $12,0=1.1(27) b$ \\
\hline & 1,0 & $2,7 \pm 0,7(21) a$ & $5,5 \pm 1,6(21) b$ & $8,9=1,0(21) a$ & $12,0=1,0(21) b$ \\
\hline & 3,0 & $2,5 \pm 0,7(29) a$ & $5,1 \pm 1,3(27) b$ & $9,3 \pm 1,0(27) \mathrm{a}$ & $12.7 \pm 1.2(27) b$ \\
\hline & 5,0 & $2,5 \pm 0,9(18) a$ & $6.2=1.1(18) a$ & $9.4 \pm 1,0(18) a$ & $12,9=1,3(18) a$ \\
\hline Helianthus & 0,0 & $2,1 \pm 0,3(50) c$ & $4,3 \pm 0,5(50) c$ & $6.2 \pm 0,4(50) c$ & $8,8=0,6(50) c$ \\
\hline \multirow[t]{4}{*}{ annuus } & 0.5 & $2,9 \pm 0,6(20) a$ & $4,9=0,4(16) b$ & $8,1 \pm 1,5(16) b$ & $11.9 \pm 1,3(16) b$ \\
\hline & 1,0 & $2,7 \pm 0,6(23) a b$ & $5,0=0,8(22) b$ & $8,3 \pm 1,4(22) b$ & $12.3 \pm 1.4(22) b$ \\
\hline & 3,0 & $2,6 \pm 0,6(21) a b$ & $4.8=1.1(19)$ bc & $8,7 \pm 1,4(19) b$ & $13,4=1,5(19) b$ \\
\hline & 5,0 & $2,4 \pm 0,5(7) b c$ & $6,9 \pm 1,5(7) a$ & $9,9 \pm 1,3(7)$ a & $13,7=1,0(7) \mathrm{a}$ \\
\hline Gynura & 0.0 & $2,1 \pm 0,3(50) b$ & $4,3=0,5(50) b$ & $6,1 \pm 0,4(50) b$ & $8.5 \pm 0.5(50) \mathrm{d}$ \\
\hline \multirow[t]{4}{*}{ procumbens } & 0,5 & $2,3 \pm 0,6(50) a$ & $4,6=0,7(50) a$ & $6,3 \pm 0,6(50) b$ & $8,8 \pm 0,6(50) c$ \\
\hline & 1,0 & $2,4 \pm 0,6(49) a$ & $4,5 \pm 0.7(49) a b$ & $6,3 \pm 0,6(49) b$ & $9,0 \pm 0,8(49) b c$ \\
\hline & 3,0 & $2,4 \pm 0,6(50) a$ & $4.5 \pm 0,5(49) a b$ & $7,3 \pm 0,5(49) a$ & $9,2 \pm 0,8(49) b$ \\
\hline & 5,0 & $2,4 \pm 0,6(49) \mathrm{a}$ & $4,5 \pm 0.5(49) a b$ & $7,4 \pm 0,6(49)$ a & $9,8 \pm 0,9(49) a$ \\
\hline Artemisia & 0,0 & $2,1 \pm 0,5(50) c$ & $4,4 \pm 0,5(50) c$ & $6,2 \pm 0,4(50) c$ & $9,0 \pm 0,7(50) c$ \\
\hline \multirow[t]{4}{*}{ vulgaris } & 0,5 & $2,9 \pm 0,9(20) a b$ & $5,1 \pm 0,6(18) b$ & $8,0=1,0(18) b$ & $11,6 \pm 1,2(18) b$ \\
\hline & 1,0 & $3,0 \pm 0,8(36) a$ & $5,1=0,6(35) b$ & $8,3 \pm 1,0(35) b$ & $11.8 \pm 1.3(35) b$ \\
\hline & 3,0 & $2,8 \pm 0,7(26) a b$ & $5,0=0,6(24) b$ & $9,0 \pm 1,6(24) a$ & $11,7 \pm 1,7(24) b$ \\
\hline & 5,0 & $2,5=0,8(13) b$ & $5,7 \pm 2,0(9) a$ & $9,3=0,7(9) \mathrm{a}$ & $13,1 \pm 1,4(9) a$ \\
\hline Sonchus & 0,0 & $2,0 \pm 0,1(50) c$ & $4,1 \pm 0,2(50) c$ & $5,7=0,5(50) c$ & $8,5 \pm 0,6(50) d$ \\
\hline \multirow[t]{4}{*}{ arvensis } & 0,5 & $2,5=0,8(50) b$ & $4,9=0,5(50) b$ & $6.7=0.7(50) b$ & $9,8 \pm 0,8(50) c$ \\
\hline & 1,0 & $2,7 \pm 0,9(49) a b$ & $5.1 \pm 0.4(49) b$ & $7,0=0,8(49) a$ & $10,8=1,1(49) a$ \\
\hline & 3.0 & $2,8=0,9(50) a$ & $5,0=0,6(50) b$ & $7,1=0,9(50) a$ & $10,2=1,1(50) b c$ \\
\hline & 5.0 & $2,9 \pm 1,0(50) a$ & $5,6 \pm 0,8(50) a$ & $7,2 \pm 0.7(50) a$ & $10,3 \pm 1,1(50) b$ \\
\hline
\end{tabular}

ding dengan kontrol. Perlakuan ekstrak pada semua tingkat konsentrasi uji mengakibatkan penghambatan perkembangan pada seciap instar larva. Pengaruh ekstrak meningkat dengan bertambahnya konsentrasi.

Dari keenam ekstrak yang diuji, empat diantaranya menunjukkan penghambatan perkembangan larva $S$. litura dari instar II ke instar VI yang cukup berarti dibandingkan dengan kontrol yaitu B. balsamifera memperpanjang perkembangan larva antara $0,7-2,8$ hari, E. scaber antara 3,0-3,9 hari, $H$. annutus antara 3,1-4,9 hari, dan $A$. vilgaris antara 2,6-4,1 hari, sedangkan untuk ekstrak $G$. procumbens dan $S$. anvensis udak begitu mencolok dibandingkan ekstrak yang lain yaitu berturut-turut antara $0,3-1,3$ hari dan 1,0-1,5 hari.

Dari perendaman bahan dalam metanol dengan perbandingan 1:10 $(\mathrm{w} / \mathrm{v})$ dihasilkan ekstrak kasar $B$. balsamifera sebanyak $11,6 \mathrm{~g}$ dari $100 \mathrm{~g}$ bahan kering, E. scaber scbanyak $11,9 \mathrm{~g}$ dari $100 \mathrm{~g}$ bahan, $H$. annus sebanyak 8,7 gr dari $70 \mathrm{~g}$ bahan, G. proctumben. sebanyak 2,8 g dari $100 \mathrm{gr}$ bahan segar, A. pulgaris sebanyak $7,8 \mathrm{~g}$ dari $100 \mathrm{~g}$ bahan, dan $S$. anensis sebanyak $13,7 \mathrm{~g}$ dari $100 \mathrm{~g}$ bahan. 
Senyawa-senyawa yang terdapat dalam masing-masing ektrak ada kemungkinan adalah alkaloid, terpenoid, glikosida, atau diterpenoid. Menurut Robinson (1991) senyawa-senyawa tersebut merupakan senyawa yang rasanya pahit, dan sebagian besar jenis bahan tumbuhan sumber ekstrak memiliki rasa yang pahit.

Sebagian besar ekstrak bersifat fitotoksik terutama pada konsentrasi $>1 \%$. Menurut Prijono (1999), ekstrak kasar cenderung fitotoksik pada konsentrasi $>0,5 \%$ karena biasanya mengandung komponen non polar yang berwujud minyak atau cairan pekat yang dapat merusak lapisan lilin.

Secara umum empat dari enam ekstrak yang diujikan memiliki aktivitas kematian yang cukup baik, dan pengaruh atau cara kerjanya terhadap kematian relatif cepat dan pada umumnya cenderung aktif pada larva instar II. setelah larva mencapai instar III, kematiannya sangat rendah atau sama sekali tidak ada meskipun larva masih memakan daun perlakuan (Tabel 1) dan dapat dipastikan dapat bertahan hidup hingga instar akhir (instar VI).

Menurut Frank (1995) sifat toksik atau efek racun suatu zat tergantung pada dosis dan lamanya pemaparan, jenis spesies, jenis kelamin, umur, gizi, dan hormon. Gejala kematian pada larva $S$. litura yang disebabkan oleh perlakuan ekstrak yaitu tubuh larva yang keracunan mengecil dan mengering. Kematian cenderung meningkat dengan meningkatnya konsentrasi.
Empat jenis ekstrak yaitu $B$. balsamifera, E. scaber, H. annuus dan A. vulgaris pada umumnya memberikan pengaruh kematian terhadap S. litura yang cukup baik pada konsentrasi $\geq 0,5^{\circ} \%$ kecuali untuk ekstrak B. balsamifera, pada konsentrasi $0,5 \%$, kematian larva rendah atau dapat dikatakan aktivitas ekstrak terhadap kematian tidak aktif. Pengaruh kematian cukup tinggi mulai terjadi pada konsentrasi $\geq 3 \%$. Menurut Prijono (1999), ekstrak yang tidak aktif pada konsentrasi $0,5 \%$ disebabkan karena senyawa yang terkandung di da-lamnya kurang aktif, tetapi kandungan-nya rendah.

Peningkatan konsentrasi ekstrak yang diuji tidak selalu diikuti oleh peningkatan kematian ini tergantung dari senyawa aktif yang terkandung dalam ekstrak. Ekstrak kasar diketahui memiliki beragam senyawa, yang masingmasing senyawa tersebut memberikan pengaruh terhadap aktivitas yang dihasilkan senyawa-senyawa tersebut masingmasing dapat bersifat toksik, penolak (repellent), antifeedant, atraktan (penarik) atau bias bersifat sebagai IGR (Insect Growth Regulatory).

Secara umum dapat dinyatakan bahwa keenam jenis ekstrak memiliki aktivitas penghambatan makan. Penghambatan makan cenderung meningkat dengan meningkatnya konsentrasi dan pada umumnya mempunyai korelasi positif dengan mortalitas larva yang mana pada persen penghambatan yang tinggi (jumlah bahan yang dimakan 
sedikit) larva mengalami kelaparan yang kemudian diikuti oleh kematian. Korelasi negatif antara penghambatan makan dengan mortalitas mungkin disebabkan larva tersebut lebih tahan untuk tetap hidup dengan mengkonsumsi makanan dalam jumlah sedikit atau senyawa yang menyebabkan kematian tersebut dalam jumlah sedikit karena larva mengkonsumsi makanan yang mengandung senyawa tersebut sedikit, sehingga larva tidak mati.

Penghambatan makan baik pada metode pilihan dan non pilihan tidak terlalu menunjukkan perbedaan yang mencolok, namun secara umum pengujian dengan metode non pilihan memberikan persen penghambatan yang lebih tinggi dibandingkan dengan metode pilihan. Selain bersifat sebagai antifeedant dan insektisida, empat dari enam ekstrak yaitu B. balsamifera, E. scaber, H. annun, dan A. mu/garis juga menun-jukkan adanya efek penghambatan perkembangan larva dari instar II ke instar VI yang cukup baik yaitu dapat memperpanjang perkembangan rata-rata 2 hingga 3 hari lebih lama dibandingkan dengan kontrol, sedangkan 2 ekstrak lainnya, G. procumbens dan S. arvensis hanya dapat memperpanjang antara 1 hingga 1,5 hari lebih lama dibanding kontrol.

Efek penghambatan ini mungkin disebabkan oleh adanya efek penghambatan akcivitas makan. Menurut Frazier dan Chyb (1995) beberapa senyawa penghambat makan dapat bersifat sebagai penolak atau bersifat toksik pada serangga hama. Penghambatan makan akan berpengaruh terhadap fisiologi serangga dan ini akan mempengaruhi perkembangannya atau mungkin berhubungan dengan mortalitas. Menurut Dadang (1999) pertumbuhan dan perkembangan serangga dipengaruhi oleh kualitas dan kuantitas makanan yang dikonsumsi.

\section{KESIMPULAN}

Empat jenis ekstrak yairu $B$. balsamifera, E. scaber, H. antuts dan A. vu/garis memberikan pengaruh ke-matian (mortalitas), penghambatan akti-vitas makan, dan dapat memperpanjang lama pengkembangan larva $S$. litura. Secara umum semua aktivitas meningkat dengan meningkatnya konsentrasi. Pengaruh kematian tertinggi ditunjukkan oleh ekstrak $H$. anmuts dengan aktivitas sedang sampai agak kuat, kemudian diikuti oleh A. vulgaris (agak lemah) sampai agak kuat), E. scaber (sedang sampai cukup kuat) dan B. balsamifera (tidak aktif sampai sedang).

Penghambatan aktivitas makan tertinggi hingga terendah berturut-turut adalah B. balsamifera, E. scaber, A. vulgaris, H. annus, G. procumbens, dan S. anensis,

Pengaruh penghambatan perkembangan larva dari instar II ke V1 tertinggi ditunjukkan olch ekstrak $H$, anmms yaitu sekitar 3,1-4,9 hari, kemudian di-ikuti oleh A. vulgaris $(2,6-4,1$ hari), E. siaber (3,0-3,9 hari), dan B. balsamifera $(0,7-2,8$ hari). 
Gejala kematian S. litura yang diberi petlakuan ekstrak secara umum sama untuk semua jenis ekstrak, yaitu tubuh larva yang keracunan mengecil dan mengering.

\section{DAFTAR PUSTAKA}

Arifin M. 1989. Ambang Ekonomi Ulat Grayak Spodoptera litura pada Tanaman Kedelai Varietas Orba. Jurnal Penclitian Pertanian 9:71-77.

Amang, B. dan M.H. Sawit. 1996. Ekonomi kedelai. Dalam Amang, B., MH. Sawit, $\mathrm{A}$. Rachman, penyunting. Ekonomi Kedelai di Indonesia. Kerjasama Badan Urusan Logistik dengan Penerbit IPB Press, ang. gota IK.API. Bogor: IPB Press. p. 1-28.

Dadang. 1999. Sumber Insektisida tlami Dalamr. Nugroho, BW., Dadang, dan D. Prijono. (Penyunting). Bahan Pelatihan Pengembangan dan Pemanfaatan Inscktisida Alami. Pusat Kajian Pengendalian Hama Terpadu, IPB, Bogor, 9-13 Agusrus 1999.

Frazicr, JL. and S. Chyb. 1995. Use of Feeding Inhibitor in Insect Control. In Gerrit de Boer RCF. (Eds.). Regulatory Mechanism in Insect Feeding. New York: Chapman and Hall. p. 364.377.

Frank, CLU, 1995. Toksikologi Dasar: Asas Organ Sasaran dan Penilaian Resiko.

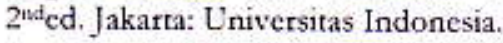

Isman, M.B. and E. Rodriguez. 1983. Larval Growth Inhibitors from Spesies of Parthenium (Asteraceac). Pytochemistry 22:2709-2713.

Kardinan, A. 2000. Pestisida Nabari. Depok: P'T Pencbar Swadaya. $80 \mathrm{p}$.
Metcalf, R.L. 1982. Insecticide in Fest Management. In Luckmann, W.H., and Metcalf RL. (Eds.). Introduction to Insect Pest Management, 2nd. New York: John Wiley and Sons. p. 217-253.

Prijono, D. 1998. Insecticidal of Meliacenus Seed Extract Against Crocidolomia Binotalis Zeller (Lepidoptera: Pyralidac). Bull HPT 10:1-7. 1999. Prospek dan Strategi Pemanfaatan Insektisida Alami Dalam: Nugroho, BW, Dadang, dan D. Prijono, (Penyunting). Bahan Pelatihan Pengembangan dan Pemanfaatan Inscktisida Alami. Pusat Kajian Pengendalian Hama Terpadu, IPB, Bogor, 9-13 Agustus 1999.

Robinson, T. 1991. Kandungan Organik Tumbuhan Tinggi $6^{\text {th }}$, (Editor). Bandung: Institut Teknologi Bandung.

Regnault-Roger, C. 1997. The Potential of Botanical Essential Oils for Insect Pest control. Integrated Pest Management Rev.. 2:25-34.

Siebertz. R., P. Proksch, and L. Wittc. 1990. Accumulation and Biosynthesis of The Chromenes Precocen I and II in Ageratum baustontanum. Phytochemistr 29;21352138.

Tarumingkeng, R.C. 1992. Insektisida; Sifat, Mekanisme Kerja dan Dampak Penggunaannya. Jakarta: P'I Sunar Surya Megah Perkasa. $250 \mathrm{p}$.

S.AS Institute. 1990. S.LS/STA Lser's quide, version 6, volume 2, $4^{\text {th }}$. (Eds). Cary (North California): S.AS Instirure.

Steel, R.G.D. dan JH. Torrie. 1993, Prinsip dan Prosedur Statistika. Sumantri, B., Penterjemah. Jakarta: Gramedia Pustaka Utama. Terjemahan dar: Principle and Procedures of Statistical: Abiometrical Approach. 